\title{
Beyond "natural-disasters-are-not-natural": the work of state and nature after the 2010 earthquake in Chile
}

\author{
Kevin A. Gould ${ }^{1}$ \\ M. Magdalena Garcia \\ Jacob A.C. Remes \\ Concordia University, Quebec, Canada \\ Pontificia Universidad Católica de Chile, Chile \\ State University of New York-Empire State College, USA
}

\begin{abstract}
Since the 1970s, human ecologists, geographers, Marxian political economists and others have insisted that there is no such thing as a 'natural' disaster. This assertion opened a space not only for exploring socioeconomic conditions that render marginalized populations vulnerable to natural hazards, but also for the formation of a field, the political ecology of hazards. A few political ecologists further interrogated the idea of a natural disaster, asking how different notions of 'the natural' circulate in post-disaster politics and with what effects. This article extends the latter approach by documenting how interconnected categories of 'nature' and 'state' were mutually constituted by narratives of politicians and elites after Chile's 2010 earthquake and tsunami. Drawing on media reports, we identify three distinct pairings of state/nature: (1) nature as manageable and the state as manager; (2) nature as out of control and the state as a police state; and (3) nature as financial opportunity and the state as prudential. Influenced by socioeconomic and historical factors, these state/nature pairings contradicted and reinforced one another in the disaster's aftermath and were deployed to reinforce top-down-rather than democratic — strategies of post-disaster reconstruction. This case offers an unusual approach to disaster politics by tracing how entwined and power-laden categories of state and nature condition the governance of disaster reconstruction processes.
\end{abstract}

Key words: disaster, state, nature, socionature, political ecology of hazards, media disaster, earthquake, Latin America, Chile, 27F

\section{Résumé}

Depuis les années 1970, des écologistes humains, des géographes, des économistes marxistes et d'autres ont insisté sur le fait qu'il n'y a pas une telle chose comme une catastrophe «naturelle». Cette affirmation a ouvert un espace non seulement pour explorer les conditions socio-économiques qui rendent les populations marginalisées vulnérables aux risques naturels, mais aussi pour la formation d'un champ, l'écologie politique des risques. Quelques écologistes politiques ont encore interrogé l'idée d'une catastrophe naturelle, et demandant comment les différentes notions de «naturel» circulent dans la politique post-catastrophe et avec quels effets. Cet article étend cette dernière approche en montrant comment les catégories reliées entre elles de «nature» et «état» ont été mutuellement constitués par les récits des politiciens et des élites après le séisme

${ }^{1}$ Dr. Kevin A. Gould, Associate Professor, Department of Geography, Planning and Environment, Concordia University, 1455 de Maisonneuve Blvd. W. Montreal, Quebec, H3G 1M8, Canada. Email: Kevin.gould "at" concordia.ca. M. Magdalena García, Profesor Asistente, Instituto de Geografía, Pontificia Universidad Católica de Chile, Santiago, Chile. Email: mmgarcia "at" uc.cl. Dr. Jacob A.C. Remes, Assistant Professor and Mentor, Metropolitan Center, State University of New York-Empire State College, NY, USA. Email: jacob.remes "at" esc.edu. The authors wish to thank two anonymous referees for their insights as well as Rosalind Bresnahan, Emilie Cameron, Rosemary Collard, Jessica Dempsey, Pablo Mendez, Ted Rutland, Manuel Tironi and Tracy Zhang for their feedback on earlier drafts of this article. We also recognize the Department of Geography and Planning at the University of Toronto where the final manuscript was completed, and the students of Geography 300 at Concordia University for their reflections on culture/nature. Research funding acknowledgement: "Observatoire universitaire de la vulnérabilité, la résilience et la reconstruction durable - Euvre durable", Fonds Québécois de la Recherche en Sciences Humaines et Culture - FQRSC (2008-2017). The authors take responsibility for all errors that remain. 
et le tsunami de 2010 au Chili. En utilisant les rapports des médias, nous identifions trois paires distinctes de l'Etat/nature: (1) la nature comme gérable et l'état en tant que gestionnaire; (2) la nature comme hors de contrôle et l'Etat comme un Etat policier; et (3) la nature comme une opportunité financière et l'État comme prudentiel. Influencé par des facteurs socio-économiques et historiques, ces appariements Etat/nature contredits et se renforçaient mutuellement dans la suite de la catastrophe. Ils ont été déployés pour renforcer les stratégies top-down (plutôt que démocratique) de reconstruction post-catastrophe. Ce cas offre une approche inhabituelle à la politique en cas de catastrophe, en traçant comment les catégories d'Etat et de la nature sont enlacés et chargés avec le pouvoir, et conditionnent la gouvernance des processus de reconstruction en cas de catastrophe.

Mots clés: catastrophe, état, la nature, la socio-nature, catastrophe médiatique, tremblement de terre, l'Amérique latine, le Chili, 27F

\title{
Resumen
}

Desde la década del 1970, los ecologistas humanos, los geógrafos, los economistas políticos marxistas y otros han insistido que los desastres "naturales" no existen como tal. Ésta afirmación ha abierto un espacio no sólo para explorar las condiciones socioeconómicas de poblaciones que son vulnerables a los riesgos naturales, sino también para la conformación de una línea de investigación, la ecología política de los riesgos. Algunos ecologistas políticos han ido más allá del cuestionamiento sobre la idea de "desastre natural" preguntándose cómo diferentes nociones de lo "natural" ha circulado en las políticas post- desastres y cuales han sido sus efectos. Este artículo se extiende desde este último enfoque, documentando como las categorías interconectadas de "natural" y "estado" se constituyen de manera conjunta entre las narrativas de los políticos y de las elites después del terremoto y tsunami ocurridos en Chile en el 2010. Sobre la base de lo publicado por los medios de comunicación, se identifican tres parejas distintas en que se relaciona estado y naturaleza: (1) la naturaleza como manejable y al estado como gerente o administrador, (2) la naturaleza fuera de control y el estado como un estado policial, y (3) la naturaleza como una oportunidad financiera y el estado como prudente. Influenciado por factores socioeconómicos e históricos, estos emparejamientos estado / naturaleza contradicen y se refuerzan mutuamente una y otra vez en las secuelas de la catástrofe y fueron desplegadas para reforzar estrategias top down, en lugar de estrategias democráticas de reconstrucción post-desastre. Este caso ofrece un enfoque inusual a las políticas de desastres mediante el trazado interconectado de cómo el poder del estado y la naturaleza condicionan la gobernabilidad de los procesos de reconstrucción de desastres.

Palabras clave: Desastre, estado, naturaleza, socionaturaleza, desastres en los medios de comunicación, terremoto, América Latina, Chile, 27F

\begin{abstract}
从M0年代开始 人类生态学家 地理学家，马克思主义政治经济学家和其他的学者开始虽调‘自然的灾害并不存在。这个题 论拓展了很大的研究空间, 不仅启发了探讨关于什么样的社会经济条件会使边缘化的社会群体对自然 威胁的更敏感脆弱, 而且, 这个断言也为建立一个关于政治生态灾难研究的领域打开了局面。特别是 有一些政治生态学家，他们进一步探讨“自然灾害”的理念，以及关于自然灾害的不同的定义是如何传 播与影响灾难后的政治活动。本文采用并延伸了这个研究方法来阐述 2010 年智利大地震和海啸后政客 和社会精英对自然灾害的言论是如何起到构成”自然”和“国家”这两个相互连结的意识范畴。通过分析 媒体的报道, 我们发现了三个不同的“自然 / 国家”言论范畴组合。第一, 自然是可以管理的, 国家是 起到一个管理人的作用。第二, 自然是不受控制, 国家是起到一个维持治安的作用。第三, 自然是 一个经济机遇, 国家是必须谨慎地经营它。这些言论的形成受到社会经济和历史条件的影响。我们发 现, 这些不同的观点互相抵制但同时也加强了这些言论共同的意识形态基础, 特别是它们被用来加强 政府实行自上而下，非民主性的“难后”重建策略。所以这个案例为我们提供了一个不同寻常的角度来 研究灾难政治学, 追述被纠缠一起且有很大社会力度的“自然/国家”两个意识范畴是如何为政府的难 后重建治理提供了必要的與论条件。
\end{abstract}

\section{Introduction}

For decades political ecologists have been arguing that there is no such thing as a natural disaster. Instead they claim that the idea of a 'natural' disaster conceals the social and political processes that make some people and populations more or less vulnerable to natural hazards such as earthquakes, hurricanes, etc. 
(Comfort et al. 1999; Gaillard et al. 2014; Hewitt 1983; O'Keefe et al. 1976; Wisner, Gaillard, and Kelman 2012). Although this intervention has opened important spaces for re-conceptualizing disaster and for reducing disaster risk, the critique of the 'natural' can be further extended in useful ways. Rather than rejecting the naturalness of disasters as false, a few political ecologists have explored how particular understandings of the 'natural' influence post-disaster responses and policies designed to reduce social vulnerability; (Collins 2009; Goemans and Ballamingie 2013; Mustafa 2005; Oliver-Smith 2002). This paper extends the latter antiessentialist political ecology approach to explore an understudied aspect of disaster politics in the aftermath of an earthquake and tsunami that struck Chile on 27 February 2010 (hereafter 27F consistent with Chilean usage).

The earthquake and tsunami resulted in the deaths of at least 521 people, affected $75 \%$ of the Chilean population, damaged or destroyed approximately 650,000 houses, and caused massive damage to infrastructure throughout central and southern Chile (Gobierno de Chile 2010: 5). In the days and weeks that followed 27F, politicians sought to mobilize people and resources by formulating narratives to connect the meaning of the event with the capacity of the Chilean state. We study this meaning-making work by examining narratives in print media, focusing specifically on the shifting meanings of 'nature' and 'state.' Rather than evaluating if politicians understood the extent of the natural disaster or the limits of state capacity, we trace how politicians radically and repeatedly reformulated these two powerful and multivalent categories-nature and state-to justify different political projects. Ultimately, our analysis reveals a contested process, strongly influenced by historical conditions and entrenched habits of thought, through which the effects of the earthquake and tsunami were produced as a problem needing a neoliberal solution.

This article begins by situating our analysis in relation to the political ecology of hazards (Blaikie et al. 1994), paying particular attention to how scholars in this field have engaged with the 'naturalness' of 'natural disaster.' We argue that a focus on the power-laden connections between the categories of nature and state reveals a useful vantage for analyzing the politics of disaster. After describing the geographical and historical context of 27F, we examine three nature-state pairings that emerged in the aftermath of $27 \mathrm{~F}$ and justified particular forms of government action. Each of these has a specific genealogy in Chile but also correspond to broader, global discourses of state and nature. 'Nature' is first imagined as dangerous but nevertheless able to be managed by a 'state', which has the necessary capacity and expertise to manage nature's threat. This vision of the Chilean state we call the Managerial State; it corresponds to the 20th-century progressive welfare state. The Managerial State and manageable nature rapidly come undone and are largely replaced by a vision of nature, including human nature, as dangerously out of control and requiring direct, violent action-a police state-for the benefit of the population. This arrangement we describe by its legal name, the State of Catastrophe. The third arrangement, corresponding to the international neoliberal project, conceives of nature as a site of investment and individual competition administered by a prudential and business-minded state, which we refer to as the State of Reconstruction. We conclude by considering how attention to what counts as state and nature can contribute to better understanding the politics of disaster in Chile and to a political ecology of hazards more broadly.

\section{The changing role of 'nature' in the political ecology of hazards}

Debates about the meaning and power of nature have played a crucial role in the emergence of a political ecology of hazards. During most of the $20^{\text {th }}$ century, the disaster literature understood disasters as the effects of extreme natural events which could be most effectively mitigated by modernist scientific approaches such as engineering and centralized planning (e.g. Burton, Kates, and White 1978). Critical scholars from a range of disciplines, including human ecology, human geography, and Marxian political economy, have rigorously challenged this approach, which they referred to as the hazards paradigm (Blaikie et al. 1994; Gaillard et al. 2014; Hewitt 1983; O'Keefe et al. 1976; Oliver-Smith, 1999; Steinberg 2006). At the heart of their challenge was a new analysis of nature, embodied in the often-repeated assertion, 'Natural disasters are not natural' (see Figure 1). The critical disaster scholars were not denying the existence of natural hazards such as earthquakes and hurricanes, but they argued that it was the social, political and economic relations that made people vulnerable to such events. Over the years there has been debate about how to 
theorize these relations-from Marxian dialectics to social construction to realist policy approaches and more-but there has been a long term consensus that the idea of the 'natural' in the disaster literature concealed the root causes of disaster risk and by extension the tactics necessary for reducing that risk. Ultimately, the critique of the 'nature' of the hazard paradigm generated a new approach to analyzing and managing disasters which focuses on the political, social, and economic factors that generate social vulnerability (Blaikie et al. 1994; Collins 2008, 2009; Comfort et al. 1999; Hewitt 1983; O'Keefe et al. 1976; Wisner, Gaillard, and Kelman 2012). ${ }^{2}$ Influenced by the latter scholarship, Naomi Klein's work on how states and multinational companies hijack disaster to impose neoliberal policies also pivots on a critique of the idea of the 'natural' disaster (Klein 2007; Gunewardena and Schuller 2008). In an interview about the 2010 earthquake in Haiti for example, Klein summarizes her argument saying that ". . . we have to be absolutely clear that this tragedy, which is part natural, part unnatural, must, under no circumstances, be used to, one, further indebt Haiti, and, two, to push through unpopular corporatist policies in the interests of our (United States) corporations" (Klein 2010, emphasis added). Ultimately, the critique of natural disasters as un-natural has changed the way scholars think about and manage disasters and has helped to consolidate the political ecology of hazards.

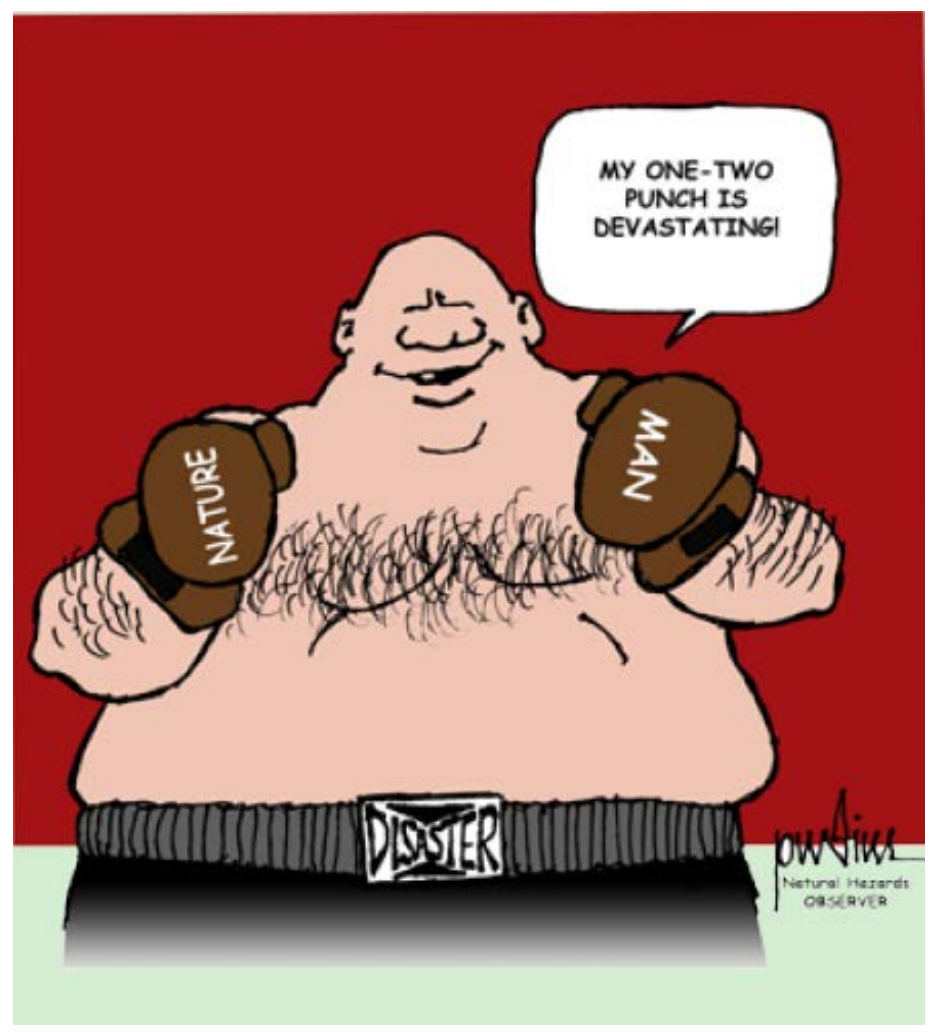

Figure 1: Cartoon version of the idea that natural disasters are not merely natural. Art by Rob Pudim, 2014.

\footnotetext{
2 As Wisner et al. (2004: 19) explain, "...the origins of the vulnerability approach ... can be located in the 1970s when authors began to question the 'naturalness' of 'natural disaster."' Although scholars have supplemented 'social vulnerability' with other organizing concepts such as 'capacities' and 'resilience' (Lizarralde et al. 2015), they have consistently emphasized that the concept of nature conceals more than it reveals (see Collins 2008 for a review of social vulnerability literature).
} 
During the mid-1990s, the broader field of political ecology was influenced by post-structural approaches exploring how power operates not only through struggles between actors and institutions but also through shifting meanings and subjects that create conditions for new kinds of politics and actions (Wisner et al. 2004; see review in Rocheleau 2008). 'Nature' became a key site for political ecologists who sought to understand the relations between meaning-making practices and power (see review in Mustafa 2005). Anthropologist Anthony Oliver-Smith drew on this scholarship to push the critique of 'natural' disasters discussed above. He recognized that the critique of nature permits disaster scholars to "link cultural and social structures and the environment in causal chains" that expose patterns of social vulnerability, but, he argued that the critique "leave[s] implicit a fundamental feature of that causation, namely the [ideological] relationship between society and nature..." (2002:30). ${ }^{3}$ Much is at stake in this critique because the western notion of nature, in which nature exists to serve the needs of humans, normalizes exploitative and environmentally destructive activities, which, in turn, contribute to the vulnerability of human populations to disaster (Merchant 1994; Plumwood 1993). In this context, a few critical hazards scholars have asked how people's shifting understandings of nature contribute to producing hazardous spaces, specifically floods and wildfires. They deliberately avoid the term 'natural hazard' because it "connotes some external nature as the key causative element" of social vulnerability (Collins 2009; Goemans and Ballamingie 2013; Mustafa 2005: 569). As Mustafa (2005) points out, refusing to take 'nature' or 'natural hazards' for granted complements the critique of natural disasters as un-natural because it opens greater possibilities for analyzing the multidimensional processes that generate social vulnerability.

In this article, we build on an emerging body of work in the political ecology of hazards literature which asks how what counts as nature informs and organizes disaster politics. This article contributes to this approach by examining how linked visions of nature and state are (re)formulated in post-disaster contexts and how such visions serve to justify particular government responses. Disasters take shape in relation to a wide array of discursive and material processes. However, we choose to focus specifically on the connections between state and nature because there is a near hegemonic assumption that states must take responsibility for citizens when 'natural' disaster strikes (Bryan 2015; Dauber 2012; Pantti, Wahl-Jorgensen and Cottle 2012: 139; See also Klein 2007). No wonder then that the post-disaster moment is saturated with claims and counterclaims about the meanings and relations of nature and state. As our analysis of the Chilean case suggests, these discursive and material contests over meaning are an important and understudied aspect of disaster politics. ${ }^{4}$ Our focus on meaning-making also responds to renewed calls to examine the role of culture in disaster studies (Cannon et al. 2014; Kreuger et al. 2015, Mercer et al. 2012) including the constructedness of foundational concepts, expertise and 'cultural conventions' that strongly influence the politics of disaster (Bankoff 2015: 12; see also Perry and Quarentelli 2005).

\section{Frames of state and nature, practices of government}

We cannot perceive natural disasters as they are; instead we apprehend their complex reality through stories, metaphors, discourses and other interpretative devices. Such meaning-making processes are political in part because they influence the possibilities for individual and collective action in post-disaster contexts (Cottle 2013; Klein 2007; Remes 2016; Sawislak 1995; Tierney, Bevc and Kuligowski 2006). Furthermore, as in the case of 27F, most people do not see or experience natural disaster first hand. Instead, they make sense of disaster through mediatized processes including newspaper reports, television, social media, etc. (on disasters as media events see Campbell 2010; Pantti, Wahl-Jorgensen, and Cottle 2012; and in the Chilean

\footnotetext{
${ }^{3}$ This was not an entirely new critique because Blaikie et al. (1994) had already described the importance of considering the root causes of disaster in the form of ideology, heritage and tradition. What was new in Oliver-Smith's intervention was the assertion that a dualistic western idea of nature could structure critical scholarship on disaster as well as disaster risk reduction.

${ }^{4}$ Our focus on the categories of state and nature does not deny the existence of actual government bureaucracies, much less physical environments. In fact, 'state' and 'nature' are powerful tools of government; for examples of the power of imagined states and natures, see (Asher and Ojeda 2012; Hansen and Stepputat 2001; Whitehead, Jones and Jones 2007).
} 
context, Jimenez-Martinez 2014). Thus, "media today perform a leading role in the public constitution of disasters, conditioning how they become known, defined, and responded to and politically aligned" (Pantti, Wahl-Jorgensen and Cottle 2012: 5). In other words, the media frames disasters such as 27F in consequential ways. By 'frame' we refer roughly to "interpretive schemas, groups of ideas, or generative metaphors that generate broad attitudes and orientations ..." (Wesselink and Warner 2010: 1). This article examines how the categories of state and nature, and their complex relations with each other, form an interpretive frame through which the Chilean press communicated the meaning of 27F. The two categories are able to take on diverse meanings on their own as well as varied relations with each other (Hansen and Steputat 2001; Williams 1976), and it is this flexibility which makes 'state' and 'nature' so useful for explaining $27 \mathrm{~F}$ and for authorizing the practices of government. By attending to changing meanings of state and nature, this article reveals the strategies and investments of government and ultimately an approach for understanding the work of power in post-disaster contexts. While we are not aware of other studies which examine how state and nature are employed to authorize post-disaster government practices specifically, political ecologists have written a great deal about how truths about state and/or nature authorize governing practices (Bridge 2014; Goldman 2005; Hansen and Stepputat 2001).

Our analysis is based on texts and images that we collected in two stages. First, we conducted a systematic search of influential national media and some international media, both by reading newspapers from the time of the disaster and conducting internet searches for television, audio, and written sources. In this first stage of textual analysis (Rose 2007), we identified key moments in which news coverage shifted from one vision of state and nature to another. In the second stage of our analysis, we examined all articles written about 27F in two national newspapers published in Santiago-El Mercurio (conservative) and La Tercera (center-right) - from 27 February to 31 March 2010 - and two other influential newspapers-La Nación (center-left, state-owned) and La Segunda (conservative)_for 27 and 28 February. To broaden our reach, we also drew on other mainstream Chilean media, including TVN (national television), Radio Cooperativa, Diario El Sur (a branch of El Mercurio in Concepción), and Diario Financiero. We also occasionally reference the international press, primarily for public statements by Chilean politicians and reportage on material conditions. In the spirit of genealogy, we look to understand the conditions in which different categories emerge or fall apart, and with what effects, not to describe fully their intricate histories. For this reason, we focused disproportionate attention on the news coverage immediately after 27F so we could describe the tumultuous and rapid transition between the first and second state-nature pairings. All translations from Spanish sources were made by the authors.

In contrast to Alison Mountz's (2010) analysis of the everyday state that shows politicians and their employees spending much of their time studying and contesting media representations of an immigration crisis (in which the imagined state was often at stake), Chilean journalists seemed to be mostly picking up the framings of politicians after 27F. There are multiple reasons why this occurred. First, two companies with close connections to the state own nearly all of the print media, second, the president of Chile during the aftermath of $27 \mathrm{~F}$ was the richest man in the country and had strong media connections; and third, violence directed at journalists during the Pinochet dictatorship, combined with the privatization of the press, led to the near elimination of watch-dog style journalism in the main newspapers. ${ }^{5}$ Illustrative of these tendencies, a quantitative analysis of the Chilean press in the year of the earthquake found that journalists introduced alternative perspectives or questioned those in authority in less than 5\% of news stories (Mellado and Lagos 2014). Thus, it becomes easier to understand why there would be a relatively close relation between media reports of $27 \mathrm{~F}$ and government policy.

We recognize that "political ecology has traditionally relied on deeply empirical and field-based research methodologies, emphasizing grassroots knowledge ... that is typically only accessible through

\footnotetext{
${ }^{5}$ Copesa (which publishes La Tercera) and El Mercurio (El Mercurio and La Segunda) have been subsidized by the state to the detriment of independent media (González 2008; Reporters Without Borders 2012). The fourth paper that we examined, La Nación is actually owned by the state. There is no left-wing paper in the capital, although there are on-line newspapers such as El Mostrador and Clarin and leftist magazines such as Punto Final, El Periodista, and The Clinic.
} 
intensive, qualitative and often semi-ethnographic research-the type of research that does not appear in the official documents" or in the newspaper (Andrews and McCarthy 2013: 9). And yet, we agree with these authors that "the heart of political ecology is not a particular set of methods . . [ [and that] a mix of approaches may serve to advance the field's overall analytical project. Thus, depending on the specific cases and research questions, different methods and evidence may be appropriate" (Andrews and McCarthy 2013: 9). In this case, our close analysis of meaning-making processes in print media contributes to the political ecology of hazards specifically as well as political ecology's long standing focus on the relationship between governance and the production of socionatures (see Mustafa 2005). Furthermore, our approach contributes to a wider critical scholarship on $27 \mathrm{~F}$ that includes many elements for a political ecology analysis bracketed in this study. This scholarship explores the multi-dimensional and multi-scalar conditions of social vulnerability of populations (Engel 2016; Hoberman 2012); the role of neoliberal policies in privatizing relief and facilitating dispossession (Letelier Troncoso and Boyco Chioino 2011; Pulgar Pinaud 2013; Sandoval and GonzalezMuzzio 2015); the politics of state, corporate, and NGO-relations during disaster response and reconstruction (Boano and Garcia 2011; Concha Saldías and Rasse Figueroa 2014; Farías 2014; Tironi 2014); the spontaneous reconfiguration of social and political life (Crispiani and Errázuriz 2013); and the ways that suffering and inequities of reconstruction awakened powerful urban social movements (Letelier Troncoso and Boyco Chioino 2013; Pulgar Pinaud 2014). This work forms a critical context for the present study by illuminating the often violent sociopolitical and institutional processes that made $27 \mathrm{~F}$ and its aftermath so dangerous. By exploring how taken for granted categories of 'state' and 'nature' are (re)imagined after 27F, this article deepens our understanding of how such sociopolitical and institutional processes were made both thinkable and implementable.

\section{Historical and institutional contexts of $27 \mathrm{~F}$}

Discourses of state and nature are linked in the context of disaster in Chile and beyond. The connections between these two categories are rooted in centuries-old histories of modernity. One of the earliest versions of the modern state, Hobbes' Leviathan, was defined in opposition to [the state of] nature (Hobbes, 1994 [1668]). Later, the western ideas of nature and the state spread in tandem as the growth of natural science and colonial power transformed meanings and material relations in Europe and the colonies (Scott 1998; Pratt 1992). Nationalisms only intensified the connections. For example, in 1812 when Simon Bolivar's army was struck by an earthquake in Venezuela, he climbed atop the ruins of a building in the middle of Caracas and famously stated "if nature opposes us, we will struggle against her and force her to obey" (McCook 2009: 50). Given that state and nature have reinforced each other for so long, it should be no surprise that they help to structure the response of elites and politicians to 27F.

On February 27, 2010, a powerful earthquake, measuring 8.8 on the moment magnitude scale, struck central and south Chile between the cities of Santiago and Concepción. Within a few hours, a tsunami struck the coast of the regions of Maule and Bío-Bío and the island Robinson Crusoe (El Mercurio 2010a). Together the earthquake and tsunami killed 521 people, damaged or destroyed approximately 650,000 homes and caused massive infrastructure damage throughout central and southern parts of the country (Gobierno de Chile 2010; La Tercera, 2011a). As a seismologically active country with a long history of strong earthquakes including eleven major quakes between 1910 and 2010 (Buchenau and Johnson 2009: 15), Chile has a number of government agencies charged with disaster preparedness, mitigation, and response, and strict building codes designed to minimize the effects of earthquakes have been in place since 1972 (Martland 2009; Rojas, Lew, and Naeim, 2010). The official national disaster agency is the National Emergency Office (Oficina Nacional de Emergencias or ONEMI); the Hydrological and Oceanographic Service of the Army (Servicio Hidrografico y Oceanográfico de la Armada or SHOA) also acts as an integral part of the state disaster apparatus by providing information and data to ONEMI. However, when the earthquake struck in 2010 it became apparent that these agencies were not ready to manage the disaster. The National Civil Defense Plan (Plan Nacional de Protección Civil)_intended "to improve the prevention and response capacities against destructive events" (El Mercurio, 2011)_lacked protocols for action after an emergency (Hoberman 2012; Radio Cooperativa 2010). 
As others have pointed out, 27F occurred at a particularly dynamic political moment and also catalyzed political change (Pulgar Pinaud 2014). President Michelle Bachelet, a socialist elected in 2006 as part of the center-left coalition Concertación, would finish her first mandate eleven days after the quake. Replacing her was Sebastián Piñera, a right-wing billionaire who was the first conservative president to be elected in Chile since the dictatorship ended in 1990. He had initially made his vast fortune--with US\$2.5bn, he is the third-richest person in Chile (Forbes 2016)--by introducing credit cards to the Chilean market. At the time Pinera was elected, the influence of leftist social movements was at low ebb after years of violent neoliberalization under Augusto Pinochet's dictatorship (1973-1990) and four elected center-left governments that had been unable to substantially dismantle Chile's exclusionary neoliberal model (1990-2010). 27F revealed these inequitable conditions, and the "seemingly sleepy" movements re-awakened and mobilized Chileans across the country at a level that had not been seen since the popular resistance to the dictatorship in the 1980s (Pulgar Pinaud 2014: 3). Thus, the earthquake would mark both a significant tectonic and a political shift for Chile (Pulgar Pinaud 2014).

The possibilities for constituting state and nature in the days and weeks after 27F were conditioned by historical, social and political economic realities, and most generally, by modernity as a social formation. The laws, policies, and economic arrangements elaborated during the Pinochet years would play a particularly important role as would the conservative programs of Chile's newly elected right-wing president. Yet the state-nature pairings and the policies which they would help to produce were never fully determined in advance. Instead, as the following sections demonstrate, complex and contingent political and material processes also influenced the formation (and decomposition) of the state-nature pairings and associated government practices.

\section{The work of 'state' and 'nature' in post-earthquake politics}

\section{Day 1: Managerial State / Manageable Nature}

Bachelet's first public response to $27 \mathrm{~F}$ suggested that the natural disaster was tragic and serious but simultaneously limited and manageable. A few hours after the earthquake she was quoted as saying, "We are facing a massive catastrophe which has caused damages that will require an enormous effort by both the public and private sectors, one of the largest [efforts] in the history of the country." She continued, "Once again our ability to deal with adversity and get back on our feet [are tested]. And we are examining every way to restore all the basic services in the country" (Bachelet 2010). These statements and other similar remarks by officials rely for their persuasiveness on a formulation already familiar to Chileans, the state as possessing the human, economic, and technical resources to overcome great challenges, including national/natural disasters. For decades government officials have used Chile's consistent economic growth to reinforce a vision of the state as having economic stability and strong institutionalism (as noted by Relea 1998). In this context, for the Bachelet administration, years of prosperity and democratic institution-building could be imagined as a savings account from which the nation could withdraw a relatively easy recovery: "Chile has the capacity, but I think it's going to take a long time and it will mean a whole lot of money" (Michelle Bachelet quoted in New York Times 2010). This vision of state responsibility and capacity would justify the deployment of vast resources for the benefit of the population in the context of post-disaster reconstruction.

If statements circulated by the Bachelet administration initially constituted the state as modern, technocratic, and managerial, these statements also constructed nature as a relatively minor force that could be managed. This state/nature pairing is consistent with and nourished by logics that have for decades structured Chile's powerful extractive industries including the country's four top exports: copper, fruit, fish products, and paper and pulp (CIA 2012). Mines, farms, fisheries, and commercial forests are not, of course, imagined as sites of undisturbed nature. Rather, they are spaces of managed nature that government, citizens, and capital shape and control for their own purposes (Scott 1998). The Chilean nation and state have long been imagined in relation to these processes of intensive extraction of natural resources which are the foundation of the national economy. This historically rooted vision of the Managerial State and its capacity to manage nature was literally built into the urban environment through building codes and protective infrastructure. 
The dualistic pairing of Managerial State and Manageable Nature was reinforced in other media representations. Figure 2 shows an image that was widely distributed beginning on the evening of the disaster. While the photograph undeniably captures an important moment, an image of a president is always symbolic of the state and especially so in the context of national disaster. Emblematic of the Managerial State, the depiction of the president gazing down on the country from a government helicopter evokes the kind of knowledge-making and control to which modernist planners and bureaucrats aspire (Scott 1998). The relative strength of the state compared to the natural disaster is also reflected by the juxtaposition of the clearly defined president on the left of the photograph and the washed out (natural) landscape below and to the right. Bachelet's facial expression reveals what might be imagined as the appropriate affect of the managerial state: calm concern. ${ }^{6}$ Whatever actual effects this image may have had on individual viewers-who each would have interpreted it from their own unique points of view-the structure and content of the image is consistent with the vision of state and nature that circulated immediately after 27F.

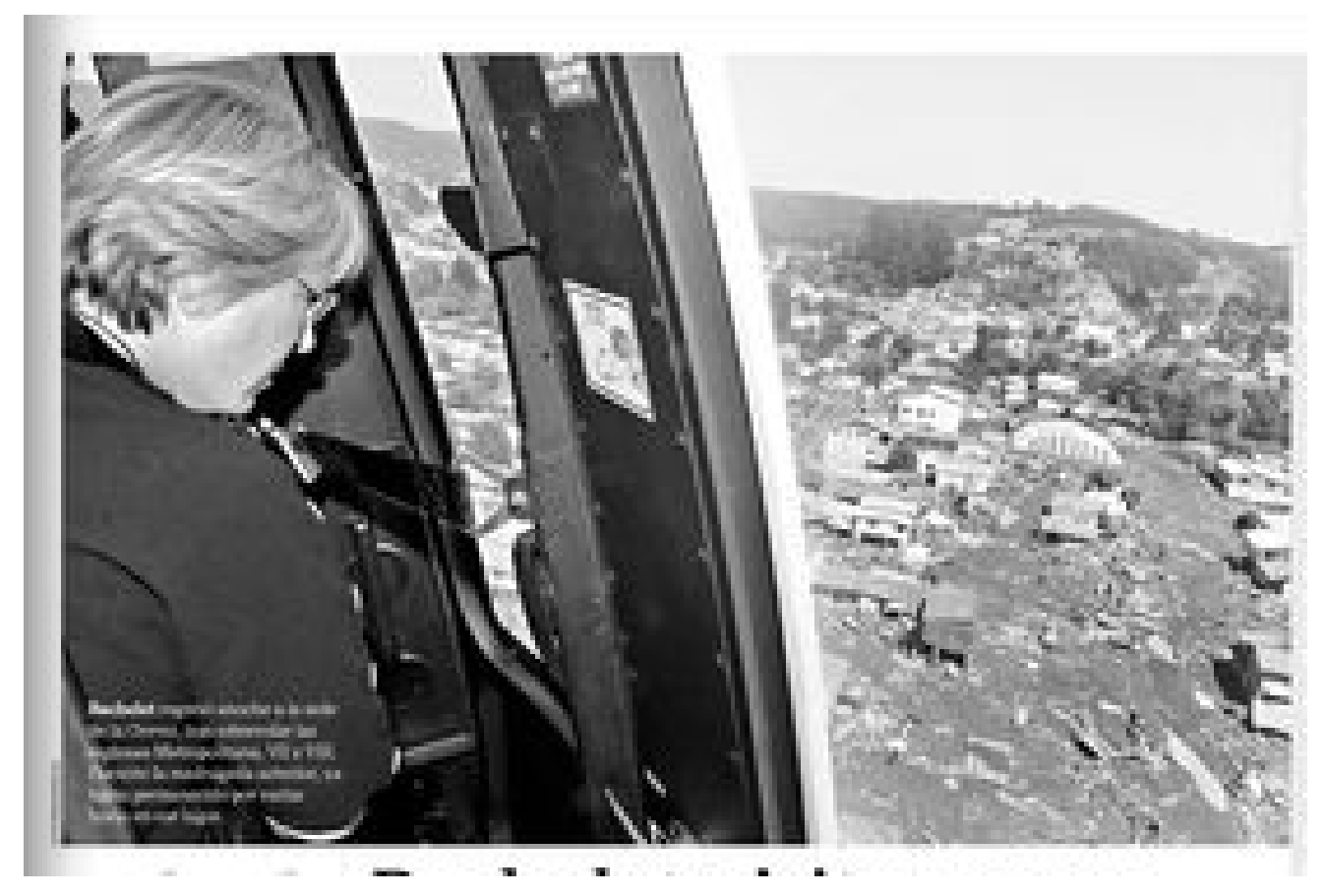

Figure 2. President Bachelet surveys the damage from a helicopter after the 2010 earthquake. Credit: Presidencia 2010.

Visions of Managerial State and Manageable Nature influenced post-disaster politics by authorizing the actions of Chilean government officials including the mobilization and celebration of expert knowledge and control of nature (see Boano and Garcia 2011 for critique), the refusal of extraordinary foreign assistance, and the insistence that ordinary governance institutions remained adequate. In short, the Managerial State was imagined to be capable of successfully managing nature.

Officials consulted national institutions that could scientifically know nature in order to manage it. For example, Foreign Minister Mariano Fernández said the decision to accept or reject international aid would

\footnotetext{
${ }^{6}$ Our discussion is also consistent with Cottle's (2013: 24) argument that ". . . culturally resonant media images [to] provide an affective charge to environmental discourses and politics of risk ..." and presumably of security as well. The image contrasts with the photos of George W. Bush looking out the window of Air Force One at damage caused by Hurricane Katrina, photos which many perceived as demonstrating his detached and uncaring attitude.
} 
have to wait for the "diagnosis of ONEMI" (El Mercurio 2010c)--presenting the government workers at ONEMI as physicians of nature and society. President Bachelet met with her ministers on the morning of 27F and with the army that afternoon. Crucially, Bachelet consulted here with the army not in its role as an armed force, but as the holder of scientific knowledge; she met with representatives of the army's special unit charged with detecting and alerting the nation in the event of tsunamis. The strength of this state-nature pairing, in which strong natural disaster would be managed by stronger state, was further reinforced by the reports of experts, engineers, and political scientists who claimed that the fact that many Chileans survived was a testament to the strength of the state, and in particular the state's enactment and enforcement of stringent building codes (Washington Post 2010a).

In an international context, the strength of Chile's regulatory, Managerial State was contrasted to the 'failed' state of Haiti, which had suffered substantially worse damage from a weaker earthquake only a few weeks earlier (Bell 2014; Katz 2013). In contrast to a dependent Haiti, Chilean officials refused international aid. The practice of refusal was repeated by multiple officials including the president, and it occurred in both national and international contexts. For example, Bachelet said on the afternoon of the quake that Chile at that point was not asking for help (El Mercurio 2010d). Heraldo Muñoz, Chile's ambassador to the United Nations, agreed, saying that "Chile was able to stand by itself." Mariano Fernández concurred: "There is no need for international aid for the moment." Chile's imagined strength was imagined to stand in contrast to the perceived weakness of its hemispheric neighbors. Fernández was quoted as saying, "We appreciate the offers but do not want to hamper the aid that many other countries, such as Haiti, may need more" (La Tercera 2010a). Refusal, however, was not only a discursive practice that reinforced the particular vision of state and nature. It also materially halted the movement of goods and services that, as it turned out, would eventually be delivered to the country (on disaster diplomacy in broader context of disaster politics, see Pelling and Dill 2010).

Instead of accepting foreign assistance, the government officials sought to activate normal, national civilian institutions for the reconstruction of the country. On the day of the disaster, the president gave a nationally broadcast address in which she sought to reassure the people and reinforce instructions that must have been given to national agencies: "The institutions are working, the system is functioning. People should remain calm. We're doing everything we can with all the forces we have" (Bachelet 2010). In (publicly) turning to national scientific expertise, refusing international aid, and relying on civilian institutions, the Bachelet Administration both acted and further constituted the vision of Managerial State and Manageable Nature.

The discourse of the Managerial State soon collapsed like the buildings that earthquake codes failed to protect. The collapse came for a variety of reasons. Firstly, the expert civil servants failed to predict the tsunami. The Hydrographic Service of the Army and the National Emergency Office did not issue a tsunami alert to harbor masters or the public even as successive waves covered parts of Chile's shoreline for two hours. Added to this failure of technical and professional expertise was a failure of the government institutions, as national agencies were unable to coordinate their activities (see Farías 2014 for a detailed account of these failures). Here it is important to note that we are not arguing that the material force of the tsunami simply caused the collapse of the Managerial State / Manageable Nature discourse. After all, the capacity of [Managerial] states to literally control the material world is always a fiction, constantly in need of discursive management (Whitehead, Jones and Jones 2007). However, the failures of technology, communication, and expert knowledge--assuredly entangled with the power of the earthquake and the tsunami--meant that this discourse lost its purchase. ${ }^{7}$ The situation would have to be reframed, and this occurred rapidly. New discourses of state and nature emerged along with new possibilities for politics.

\footnotetext{
${ }^{7}$ There is a tension between the strong-state discourses that Bachelet and her administration were deploying in the immediate aftermath of $27 \mathrm{~F}$ and the fragmented government institutions-including disaster management institutionsthat years of neoliberal policies had produced. This tension suggests not that the Bachelet administration had lost touch with reality when they addressed the population with such confidence but that natural disasters are opportunities par excellence for re-imagining and re-enacting state and nature.
} 


\section{Day 1.5: State of Catastrophe}

At a press conference the day after the disaster, President Bachelet declared the earthquake to be "an emergency without parallel in Chile's history" (Washington Post 2010b). In saying this, she acknowledged the fundamental inability of the government to completely dominate nature. "Despite our achievements, our institutional and economic solidity, and the level of development [we have] attained as a country," she said, referring to the progress of democratization and prosperity, "we will never be able to be fully protected from the ravages of nature" (Radio Cooperativa 2010). But it was not just the Bachelet administration that was reframing the meaning of the disaster and the state. Sebastián Piñera intervened from his position as president-elect, claiming: "This calamity is much deeper, much more damaging and much more serious than we thought" (Televisión Nacional de Chile 2010). Defense Minister Francisco Vidal supported this image of the disaster, strengthening Piñera's position (Diario El Sur 2010). Thirty-six hours after the earthquake, President Bachelet declared a state of catastrophe--a constitutional suspension of civil rights and liberties--in six administrative regions. This legal framework, enlivened by the contest between the sitting president and the president-elect, gave life to a new pairing of imagined state and nature which we call the State of Catastrophe.

In the discourse of the State of Catastrophe, the earthquake and the material deprivation it created, such as a lack of food and water, were imagined to provoke popular chaos. Politicians and the press equated the failure of basic technological services like water, electricity, and international communications with failures of human systems of control. In other words, the earthquake and the damage it caused was imagined as shaking loose the bonds that hold together a fragile society, so that 'real' Hobbesian human nature emerged, violent and destructive. Linking the physical and social disasters, La Tercera proclaimed in a headline that the "impact of the tsunami and looting aggravate[d the] magnitude of tragedy" (La Tercera 2010c). Similarly, the mayor of Concepción characterized the post-disaster situation as a "social revolution" (El Mercurio 2010e). As in the aftermath of Hurricane Katrina in New Orleans, images in the press of people procuring food and luxury goods helped to constitute a new class of subjects, 'looters', whose anti-social behavior was taken as evidence for the necessity of new government policies (Tierney, Bevc and Kuligowski 2006; Berger 2009; See Figure 3). In this formulation, only the most muscular and violent of government responses--the imposition of martial law, the arbitrary authority of soldiers, and the declaration of curfews--could restore society to normal levels of safety and stability. El Mercurio demanded the use of soldiers, framing it as a popular demand, a "desperate call for security forces to restore order" (El Mercurio 2010f). Nature, it seemed-including both seismological events and human nature-was dangerous and violent, held back only through a powerful and coercive state.

Just as the imagined Managerial State was conditioned and restricted by Chile's historical and material circumstances, so too was the State of Catastrophe. The Chilean constitution has included provisions for suspending rights and ordinary civil governance in times of crisis since its very first iteration in 1833 (Jiménez 1997). After a devastating earthquake in Valparaiso in 1906, the police exercised exceptionally violent discipline, including executing thieves by firing squad (Martland 2009: 74-75). But states of emergencies were elaborated and gained particular political and emotional resonance during the dictatorship of Pinochet. A new national constitution, ratified by the Pinochet regime in 1980, contained four linked but legally distinct states of exception (situaciones de excepción) including the state of catastrophe (to be declared for cases of 'public calamity'). Each of these states was designed to create the legal conditions for the use of military and other exceptional means of violence or threatened violence to control a populace, imagined as unusually restive, disruptive, or dangerous (Ríos 2009). During Pinochet's rule, states of constitutional exception were implemented on a permanent basis to curtail the rights and freedoms of citizens.

While blanket use of state of exception has not been applied to the entire country since Pinochet, the use of policing power in Mapuche territories is an everyday occurrence. Mapuche indigenous communities, long in an antagonistic and racially charged (colonial) relationship with government authorities, were scarcely mentioned in the media and received little government aid, in spite of the damage to these communities (e.g., 
BBC News 2010b). Often imagined as irrational, drunken, lazy and rebellious (and recently as terrorists) in the dominant racist popular imagination, Mapuche are subject to heavy-handed policing tactics that approach martial law (Waldman 2012). ${ }^{8}$ If like other indigenous peoples, the Mapuche are often imagined as backwards enemies of modernity and too close to nature (Franco 2006; Terwindt 2009), the earthquake was imagined as having the power to reduce non-indigenous Chileans to the same "condition of mere nature," to quote Hobbes (1994 [1668]). Citizens in affected areas were in fact often imagined by government as out of control, like the Mapuche - even while, paradoxically, they were also imagined as potential victims of their out-of-control neighbors-and thus many non-indigenous citizens were briefly subject to the kinds of state policies directed at the Mapuche. In sum, the practices authorized by the State of Catastrophe borrowed not only from Pinochet era but also from earlier regimes and from contemporary (neo)colonial strategies of government.

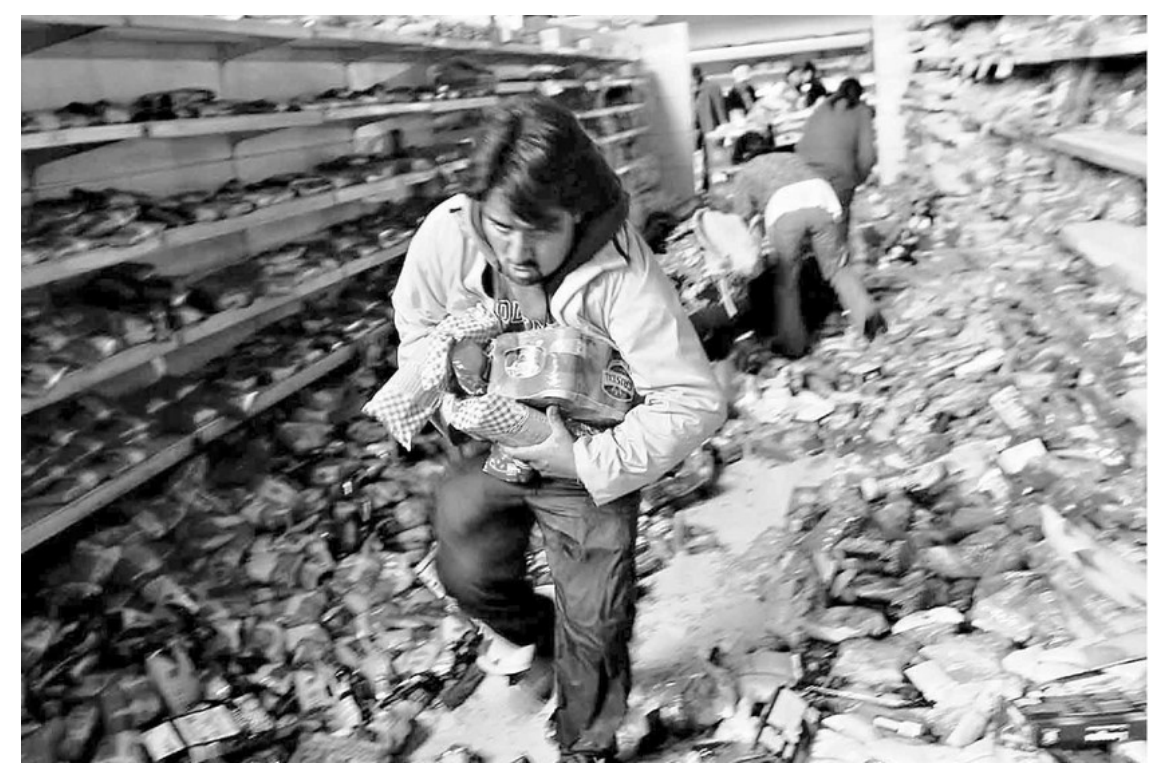

Figure 3. In the aftermath of the earthquake, the media circulated images of 'looters' obtaining food and luxury goods. Credit: Dávila, 2010.

The transition from Managerial State to State of Catastrophe was intimately connected to the political transition from Michelle Bachelet to Sebastián Piñera. A state of exception had not been implemented since the dictatorship, and the center-left Bachelet administration sought to avoid imposing one as its final act. Public Works Minister Sergio Bitar publicly fretted that it would look particularly bad for a center-left administration to end with soldiers on the street (La Tercera, 2010f). Meanwhile Piñera called for the current government to declare a State of Catastrophe immediately (La Tercera, 2010b), "This morning we have requested that the government declare state of catastrophe," the president-elect said on national television, "which will deploy all our resources, including our army which will help to restore the order and help the victims" (Televisión Nacional de Chile 2010). His language was significant because it implied personal authority to deploy the army even before his formal inauguration. Piñera thus strengthened his own political position by demanding the state of catastrophe.

The rhetoric and legal framework of the State of Catastrophe permitted the government to mobilize people and resources in extraordinary ways. Under the Managerial State, Bachelet had consulted with the

${ }^{8}$ See also Haughney's (2006) work which analyzes the complexity of material and discursive struggles between the Mapuche and the Chilean state. 
army, its authority grounded in scientific expertise; under the State of Catastrophe, Bachelet literally empowered the army, its authority grounded now in its role as the embodiment of state violence. Further, two administrative regions, Maule and Bío-Bío, were placed under direct control of the army. In the name of restoring order to a supposedly dangerous population, the army limited freedom of movement to six hours per day (noon-6:00 pm) in Concepción, the second largest city in Chile. Later curfews were also imposed in other smaller cities affected by the disaster. One newspaper's headline emphasized a specific order of events: "Concepción is under the control of the army, 11,850 troops are deployed after violent events" (La Tercera 2010e). Note how soldiers--the literal embodiment of state violence--were seen as the appropriate and expected response to apparent citizen violence. In Santiago, where the disaster caused less damage than in cities located south of the capital, one newspaper stated, "By collective psychosis shops close and [citizens] call for the presence of troops" (La Tercera 2010e). While such headlines reinforced the appropriateness of martial law, they also reflect the power of the State of Catastrophe to mobilize civil society. Citizens in Concepción, for example, not only asked that the army be deployed in the streets but also created ad hoc neighborhood civil patrols for self-defense and to protect property immediately after the earthquake (see for example, Vázquez 2010). When Piñera took power, he maintained the state of catastrophe and also extended it to the O'Higgins administrative region (La Nacion 2010). Under the State of Catastrophe, the most violent kinds of governing strategies and tactics were justified and carried out not only by the army but by the people themselves. $^{9}$

In addition to its martial aspects, the State of Catastrophe had financial and political material consequences. The official declaration of a state of catastrophe allowed for rapid shifts in budget allocation: Bachelet and then Piñera were able to spend $2 \%$ of the public budget to fund disaster response. In addition, with the collapse of the Managerial State discourse, so too collapsed the refusal to accept foreign aid. The extraordinary nature of the State of Catastrophe meant that extraordinary assistance was also required. The decision to accept international assistance, which started to arrive 72 hours after the quake, was imbricated with the enhanced power of the army, since the material aid required the mobilization of the army and other institutions to distribute it (La Tercera 2010d).

In contrast to the Managerial State, which sought to manage nature and believed it to be conquered, the State of Catastrophe saw nature as fundamentally unconquerable. In this imaginary, nature-seismic nature but especially human nature-remains an ever present danger to civilization and an excuse for internal repression. The imagined state and imagined nature remain, in this pairing, mutually constituted: nature as forever threatening to impinge on safe society, and state as the armed savior of that society, defending people from 'natural' disaster and from their own 'naturally' animalistic instincts.

\section{Day 13: State of Reconstruction}

As president-elect, Piñera continued to creatively mobilize discourses of the natural disaster and the state. A few days after he drew on the State of Catastrophe to assert himself against Bachelet, Piñera sought to distance his administration from the fatal mistakes that occurred in the first days of reconstruction. "We will not be the government of the earthquake", Piñera announced, "but the government of reconstruction" (BBC News 2010a). In his inaugural address, almost two weeks after 27F, Piñera elaborated the idea of the State of Reconstruction: "We're going to have to deal with adversity, as we have done a thousand times", he said. "That's why we will develop a plan for reconstruction and development and a fund to finance it" (Efe 2010). Reconstruction, then, was not merely a question of repairing what had been broken or the deployment of the military in the streets to protect the population; reconstruction was a financial challenge. Piñera's post-disaster policies were made possible by rendering both nature and state financial through the State of Reconstruction. Of course, Pinera did not invent this approach. The accelerated financialization of urban development is

${ }^{9}$ As with other forms of 'nature' described here, the imagined Hobbesian human nature was just that: imagined. As in other disasters, spontaneous organizing was common and included both vigilante patrols and mutual aid (Miller 2000; Pulgar Pinaud 2014; Solnit 2009; Remes 2016). 
typical of the neoliberal model, though not unique to it (see Rutland 2012), and as others have discussed, socalled natural disasters have been used by many government to fast-track neoliberal policies (Gunewardena and Schuller 2008; Klein 2007; Wisner 2001). Chile was a prototype and proving ground for this approach. After the overthrow of democratically elected president Salvador Allende in 1973, the Pinochet regime invited economists from the University of Chicago (the 'Chicago boys') to restructure the Chilean economy according to the laws of the market. Those who resisted the neoliberal policies were the targets of brutal state violence (Klein 2007).

The discursive starting point for financializing nature and state in the context of 27F was a logic of accounting, and specifically, the translation of the disaster into a single number: US\$ 30bn (Dempsey and Robertson 2012; Efe, 2010; New York Times 2010). Although that figure was contested (Ulloa and Cárdenas 2010), it allowed Piñera to argue that "there is no money to meet all the needs the disaster left [behind]" (Diario Financiero 2010). ${ }^{10}$ The logics of accounting constituted the state as inadequate to confront the disaster because it lacked the fiscal resources relative to the disaster's absolute cost. This logic and the figure itself also permitted the disaster to be translated into the science of macroeconomics; US\$ 30bn was equal to $18 \%$ of GDP (Efe 2010). Once the damage was cast in terms of GDP--and therefore as a part of the economy-there were laws of the market which must be obeyed, and which would again reconstitute the meaning of the state. According to Piñera's budget director, "The problem [of the disaster] is greater if we consider the fact that an excessive increase in public spending [to fix the damage] will provoke inflation and affect the peso", which would in turn depress exports and increase unemployment (Diario Financiero 2010). In this macroeconomic formulation the danger posed by the natural disaster is compounded by another hazard: the danger of breaking the 'natural' laws of the market. In the interests of the population, and out of respect for great danger represented by nature in its earthly and economic forms, the state is suited only to remain on the sidelines.

If the natural disaster is too dangerous for the state, then how should reconstruction proceed? Neoliberal ideology posits nature as a sphere of competition in which well-disciplined subject-workers and capitalist firms are best suited to perform (McCarthy and Prudham 2003). In this scenario, companies and markets are ideally positioned to respond to disaster, because according to natural laws of the market, when companies respond to disaster, they build the economy rather than contributing to inflation. Further, the imagined habitat for companies is the dangerous zone of cut-throat competition in which individuals and companies reap the rewards or pay the costs of their decisions. Thus, according to this logic, companies are well suited for the dangers of disaster reconstruction. In fact, for companies, at least for the most competitive ones, the dangers of competitive nature are transformed into opportunity for both efficient reconstruction and profit. In this context the state is positioned as advisor and cheerleader, best suited to designing the policies which will allow the natural market processes to operate and produce optimal solutions.

Since Pinera's neoliberal approach to reconstruction was the most sustained and influential, critical scholars have written a great deal about it. We draw from this literature to describe the kinds of practices that accompanied the cultural logics described above. First, the Chilean government provided concessions and subsidies to private contractors so that 'the market' would have the resources to repair damaged public infrastructure such as roads, hospitals, and schools (Diario Financiero 2010; Letelier Troncoso and Boyco Chioino 2011; Pulgar Pinaud 2013, 2014; Sandoval and Gonzalez-Muzzio 2015; La Tercera 2010g). ${ }^{11}$ Piñera increased money available for such efforts by dipping into the accumulated wealth of the national copper industry, taking on greater debt from international organizations such as the World Bank, and imposing austerity measures to reduce public spending (Efe 2010). Second, to insure the dynamic functioning of the market, the government loosened labor and environment regulations and liberalized monetary policy (Pulgar Pinaud 2013, 2014; Sandoval and Gonzalez-Muzzio 2015). For example, 27F was used to justify a proposal to

\footnotetext{
${ }^{10}$ Economists estimated that the infrastructure cost was about US\$ 8bn instead of the official number of US \$30bn (La Tercera 2011b).

${ }^{11}$ For example, the government transferred US\$ 626 million to the country's twenty largest real estate companies to build social housing which these companies were then permitted to sell to the survivors of the earthquake (La Tercera 2011c).
} 
reduce the need for competitive bidding and environmental assessments for obtaining government building contracts (Valenzuela and Jimeno 2010). This neoliberal approach, which some have described as disaster capitalism (Sandoval and Gonzalez-Muzzio 2015), permitted private firms to accumulate profits by reconstructing houses with shoddy materials and locating replacement housing on low value land. Working class people living in areas of high land value, especially along the coasts and in the downtown cores of cities, were massively displaced as companies rushed to develop these locations for real estate and tourism (Letelier Troncoso and Boyco Chioino 2011; Pulgar Pinaud 2014). ${ }^{12}$

In addition to policies that supported the construction and banking sectors, the State of Reconstruction also normalized practices of the retail sector and cultural industries. Between March 5th and 6th a telethon called 'Chile Helps Chile' raised over US\$ 90 million for victims of 27F (Emanuel 2014). Hosted by television personality Don Francisco, who initiated celebrity telethons in Chile in 1978, the event featured celebrities, sports stars, politicians, and business people. The telethon was aired on all television and radio stations in the country, and donations poured in from individuals and companies. Prominently displayed Chilean flags, the use of red, white and blue clothing and stage sets, and the presence of Bachelet and Piñera reminded viewers that the cost of the disaster was a national responsibility of all Chileans and obscured the power relations that had spread the impacts of the disaster unevenly across the population. In that way, the telethon was similar to nationalist fundraising campaigns that have long followed disasters around the world (for review of literature on telethons and other kinds of benefit shows, see Driessens, Joye and Biltereyst 2012). In addition to traditional donations, companies also contributed a percentage of profits from sales of designated products. In exchange for their donations and for discounting their products, companies were compensated with millions of dollars in free publicity before and during the telethon. The telethon thus equated disaster reconstruction with consumption, positioned companies and private individuals as responsible for the welfare of the population, and reduced the national executives to almost literal cheerleaders. It therefore embodied and further constituted the State of Reconstruction.

\section{Conclusion}

The idea that disasters are not natural, posited by radical geographers in the 1970s, is foundational to the political ecology of hazards and continues to be important to this day (O'Keefe et al. 1976; Wisner 1977). This intervention opened a space for analyzing the sociopolitical and institutional processes that are obscured by the imagined naturalness of so-called natural disasters. If we turn to the critical scholarship on the 2010 earthquake and tsunami in Chile, we can also see this approach at work. Rather than attempting to describe $27 \mathrm{~F}$ as a 'natural' event with certain impacts, the critical literature explores sociopolitical and material conditions that left populations vulnerable to the earthquake, e.g., Engel (2016) examines the kinds of social movements and forms of citizenship that emerged in the aftermath, and Letelier Troncoso and Boyco Chioino (2011) and Pulgar Pinaud (2013) explore the political and economic relations between state, NGOs and private sector during reconstruction. Our article contributes to this scholarship by exploring taken for granted meanings that organized post-disaster responses. Specifically, we have examined how politicians and elites justified government action by (re)formulating relations between an imagined state and an imagined nature.

Within only a few weeks of the event, government officials deployed three distinct relations between imagined state and nature to justify three different kinds of responses. Immediately after 27F, the Bachelet administration sought to project an image of the state as in control and able to manage a dangerous but nevertheless manageable nature. This state-nature pairing aimed to justify the expert practices of the government's disaster response agencies. When it became known that these agencies had failed to predict the tsunami or to recognize the extent of the damage, more conservative elements within the government including the incoming president projected a new relation in which nature was beyond the capacity of the

\footnotetext{
12 Pre-existing market arrangements also played a crucial role in reinforcing the material and epistemological conditions for the State of Reconstruction. Insurance companies paid out US\$ 8.5bn in claims and then raised their rates by an average of 50\% (Aon Benfield 2011; see also Smith 2007).
} 
state. This relation justified the use of military force to restore order to the streets of the southern and central parts of the country. After approximately two weeks, the conservative government reframed the situation a third time such that the natural disaster was too complex and costly for the state to handle, but that reconstruction should be left to the efficiency of the business sector and the market. Here we draw two conclusions. First, elites and politicians consistently justified different post-disaster responses by elaborating relationships between imagined state and nature. Second, in spite of the political differences between the center-left Bachelet administration and the right wing Piñera administration, all officials used these relations to leverage top-down, rather than democratic, approaches to governance. While others have noted the hegemony of the assumption that natural disasters are the responsibility of the state (Pantti, Wahl-Jorgensen and Cottle 2012), this article documents how powerfully this framing limits the possibilities for alternative politics; e.g. for enacting grassroots responses to disaster (Pulgar Pinaud 2014).

By examining how 27F was conceptualized at different moments during the post-disaster response, we can also learn about conflicts within the Chilean government at the time. The Bachelet administration's initial response to $27 \mathrm{~F}$ aimed to manage the disaster through existing agencies, infrastructures and budgets. Her administration tried to prevent the military from being deployed in the streets, and there was no public discussion of the use of debt to finance reconstruction. In other words, this was not going to be an overtly neoliberal response. This is significant because, as we have discussed, in Chile, the violent imposition of neoliberal policies during the 17-year dictatorship left an enduring legacy. Nevertheless, in 2010, even before the massive social mobilizations had transformed Chile's political landscape, neoliberal programs could not be trusted to simply fall into place. On the other hand, the rapidity with which conservative actors were able to capitalize on the errors of the initial response to $27 \mathrm{~F}$ and to switch the government script reveals the capacity of the new government at the beginning of its mandate. By tracing the meaning-making work of these conservative actors, this article helps to explain how the new administration made neoliberal policies thinkable and implementable in the aftermath of 27F. Further research is required to understand how this initial framing was transformed as it articulated with the claims and practices of social movements that stopped the Piñera administration from achieving many of its objectives.

\section{References}

Alonso, C. 2010. Piñera anunció 10 medidas para financiar la reconstrucción. Nación. April 18. http://www.lanacion.cl/noticias/site/artic/20100416/pags/20100416235243.html

Andrews, E., and J. McCarthy. 2014. Scale, shale, and the state: political ecologies and legal geographies of shale gas development in Pennsylvania. Journal of Environmental Studies and Sciences 4(1): 7-16.

Asher, K. and D. Ojeda. 2009. Producing nature and making the state: Ordenamiento territorial in the Pacific lowlands of Colombia. Geoforum 40(3): 292-302.

Aon Benfield. 2011. Chile: one year on. Technical report. (accessed April 15, 2012). Chicago: Aon Benfield.

Bachelet, M. 2010. Cadena Nacional: Presidenta Michelle Bachelet se dirigie a los Chilenos por el terremoto. Televisión Nacional de Chile, Mensaje presidencial por cadena nacional. March 27, 21:00 hrs.

Bankoff, G., T. Cannon, F. Kruger, and L.F. Schipper. 2015. Introduction: exploring the links between cultures and disasters. In F. Kruger, G. Bankoff, T. Cannon, B. Orlowski, and L.F. Schipper (eds.) Cultures and disasters: understanding cultural framings in disaster risk reduction. New York: Routledge. Pp 1-16.

BBC News. 2010a. Chile quake reconstruction 'to take up to four years'. March 4. http://news.bbc.co.uk/2/hi/8550140.stm (accessed April 14, 2012).

BBC News. 2010b Chile's indigenous Mapuche speak out online. March 11. http://news.bbc.co.uk/2/hi/americas/8560995.stm (accessed April 12, 2012).

BCN [Biblioteca del Congreso Nacional de Chile]. 2010. Qué es el Estado de Catástrofe. http://www.bcn.cl/de-que-se-habla/estados-excepcion-constitucional (accessed August 12, 2011).

Bell, B. 2014. Fault lines: views across Haiti's divide. Ithaca, N.Y.: Cornell University Press. 
Berger, D. 2009. Constructing crime, framing disaster: routines of criminalization and crisis in Hurricane Katrina. Punishment and Society 11(4): 491-510.

Blaikie, P., T. Cannon, I. Davis and B. Wisner. 1994. At risk: natural hazards, people's vulnerability and disasters. New York: Routledge.

Boano, C. and M. Garcia. 2011. Lost in translation? The challenges of an equitable post-disaster reconstruction process: lessons from Chile. Environmental Hazards 10 (3-4): 293-309.

Bridge, G. G. 2014. Resource geographies II: the resource-state nexus. Progress in Human Geography, 38(1): 118-130.

Bryan, J. 2015. War without end? Military humanitarianism and the limits of biopolitical approaches to security in Central America and the Caribbean. Political Geography 47: 33-42.

Buchenao, J. and L.L. Johnson. 2009. Introduction: earthquakes and Latin American political culture. In J. Buchenao and L.L. Johnson (eds.) Aftershocks: earthquakes and popular politics in Latin America Albuquerque: University of New Mexico Press. Pp 1-17.

Burton, I., R.W. Kates and G.F. White. 1978. The environment as hazard. New York: Oxford University Press.

Campbell, W.J. 2010. Getting it wrong: ten of the greatest misreported stories in American journalism. Berkeley: University of California Press.

Cannon, T., L.S. Schlipper, G. Bankoff and F. Krüger (eds. with others). 2014. World Disasters Report 2014: focus on culture and risk. Geneva: International Federation of Red Cross and Red Crescent Societies.

Concha Saldías, C., and A. Rasse Figueroa. 2014. La Ruta de las Caletas del Maule: Sobre la articulación entre sector público, privado y sociedad civil en los procesos de reconstrucción posterremoto. Revista de geografía Norte Grande 59: 165-184.

CIA [Central Intelligence Agency]. 2012. Chile. In CIA World factbook. https://www.cia.gov/library/publications/the-world-factbook/geos/ci.html (accessed March 17, 2012).

Comfort, L., B. Wisner, S. Cutter, R. Pulwarty , K. Hewitt, A. Oliver-Smith, J. Wiener, M. Fordham, W. Peacock and F. Krimgold. 1999. Reframing disaster policy: the global evolution of vulnerable communities. Environmental Hazards 1(1): 39-44.

Collins, T.W. 2008. The political ecology of hazard vulnerability: marginalization, facilitation and the production of differential risk to urban wildfires in Arizona's White Mountains. Journal of Political Ecology 15(1): 21-43.

Collins, T.W. 2009. The production of unequal risk in hazardscapes: an explanatory frame applied to disaster at the US-Mexico border. Geoforum 40(4): 589-601.

Cottle, S. 2013. Environmental conflict in a global, media age: beyond dualisms. In L. Lester and B. Hutchins (eds.), Environmental conflict and the media. New York: Peter Lang. Pp. 19-36.

Crispiani, A. and T. Errázuriz. 2013. La reaparición de lo público: experiencias de habitación durante el posterremoto. Revista 180 31: 16-21.

Cumplido, F. 2006. Reforma constitucional en Chile. In Anuario de derecho constitucional Latinoamericano. Berlin: Konrad-Adenauer-Siftung I: 105-113.

Dauber, M.L. 2012. The sympathetic state: disaster relief and the origins of the American welfare state. Chicago: University of Chicago Press.

Dávila, M. [photographer]. 2010 Violento ingreso a supermercado [photograph]. La Tercera. March 1, 8.

Dempsey, J. and M.M. Robertson. 2012. Ecosystem services: tensions, impurities, and points of engagement within neoliberalism. Progress in Human Geography 36(6): 758-779.

Diario El Sur. 2010 Enormes daños en zona centro-sur del país. February 28. http://www.elsur.cl/base_elsur/site/artic/20100228/pags/20100228165511.html (accessed May 13, 2011). 
Diario Financiero. 2010. Según Piñera no hay fondos para hacer frente a la reconstrucción. March 16. http://www.df.cl/portal2/content/df/ediciones/20100316/cont_136087.html (accessed April 10, 2012).

Driessens, O., S. Joye and D. Biltereyst. 2012. The X-factor of charity: a critical analysis of celebrities' involvement in the 2010 Flemish and Dutch Haiti relief shows. Media Culture Society 34(6): 709-725.

Efe. 2010. Las pérdidas por el sismo en Chile ascienden a 30,000 millones de dólares. El Mundo. March 12. http://www.elmundo.es/america/2010/03/12/noticias/1268422363.html (accessed April 14, 2012).

Emanuel Korstanje, M. 2014. Chile helps Chile: exploring the effects of earthquake Chile 2010. International Journal of Disaster Resilience in the Built Environment 5(4): 380-390. On Academia

Emol. 2010. Ministro de Economía: El terremoto se ha traducido en un impulso de la actividad económica. June 8. http://www.emol.com/noticias/economia/2010/06/08/417770/ministro-de-economia-elterremoto-se-ha-traducido-en-un-impulso-de-la-actividad-economica.html (accessed April 14, 2012).

Engel, K.E. 2016. Talcahuano, Chile, in the wake of the 2010 disaster: a vulnerable middle? Natural Hazards 80(2): 1057-1081.

Farías, I. 2014. Misrecognizing tsunamis: ontological politics and cosmopolitical challenges in early warning systems. The Sociological Review 62(S1): 61-87.

Forbes. 2016. Billionaires: \#688 Sebastian Pinera. March. http://www.forbes.com/profile/sebastian-pinera (accessed March 9, 2016).

Franco, J. 2006. 'Alien to modernity': the rationalization of discrimination. Journal of Latin American Cultural Studies 15(2): 171-181.

Gaillard J.C. and I. Kelman. 2012. Framing disaster: theories and stories seeking to understand hazards, vulnerability and risk. In B. Wisner, J. C. Gaillard and I. Kelman (eds.), The Routledge Handbook of Hazards and Disaster Risk Reduction. New York: Routledge. Pp. 18-33.

Gaillard, J.C., M. Glantz, I. Kelman, B. Wisner, Z. Delica-Willison and M. Keim. 2014. Taking the 'naturalness' out of natural disaster (again). Natural Hazards Observer 38(3): 1, 14-16.

Gobierno de Chile. 2010 Plan de Reconstrucción Terremoto y Maremoto del 27 de Febrero de 2010. http://www.preventionweb.net/files/28726_plandereconstruccinagosto2010.pdf (accessed 2 December 2015).

Goemans, M. and P. Ballamingie. 2013. Forest as hazard, forest as victim: community perspectives and disaster mitigation in the aftermath of Kelowna's 2003 wildfires. The Canadian Geographer/Le Géographe canadien 57(1): 56-71.

Goldman, M. 2005. Imperial nature: the World Bank and struggles for social justice in the age of globalization. New Haven, Conn.: Yale University Press.

González, R. 2008. The media in Chile: the restoration of democracy and the subsequent concentration of media. In J. Lugo-Ocanda (ed.). The media in Latin America. Maidenhead, England, and New York: Open University Press and McGraw-Hill Education. Pp. 61-77.

Gunewardena, N., and M. Schuller (eds.). 2008. Capitalizing on catastrophe: neoliberal strategies in disaster reconstruction. Lanham, Md.: AltaMira.

Hansen, T.B and F. Stepputat. 2001. Introduction: states of imagination. In T.B. Hansen and F. Stepputat (eds.) States of imagination: ethnographic explorations of the postcolonial state. Durham, N.C.: Duke University Press. Pp. 1-40.

Haughney, D. 2006. Neoliberal economics, democratic transition, and Mapuche demands for human rights in Chile. Gainesville: University of Florida Press.

Hewitt, K. (ed). 1983. Interpretations of calamity from the viewpoint of human ecology. Boston: Allen and Unwin.

Hobbes, T. 1994. Leviathan with selected variants from the Latin edition of 1668. Indianapolis, Ind.: Hackett.

Hoberman, G. 2012. Political calculus in the engagement with a disaster risk reduction agenda: the case of the post-2010 earthquake and tsunami in Chile. Faculty Publications. Paper 3. Florida International University. 
Jiménez, F. 1997. El régimen jurídico del Estado de Catástrofe. Revista de Derecho de la Universidad Católica de Valparaíso 18: 305-314.

Jiménez-Martínez, C. 2014. Disasters as media events: the rescue of the Chilean miners in national and global television. International Journal of Communication 8: 1087-1830.

Katz, J.M. 2013. The big truck that went by: how the world came to save Haiti and left behind a disaster. New York: Palgrave Macmillan.

Klein, N. 2007. The shock doctrine: the rise of disaster capitalism. New York: Metropolitan Books.

Klein, N. 2010. Naomi Klein issues Haiti disaster capitalism alert: stop them before they shock again. Democracy Now radio. January 14. http://www.democracynow.org/2010/1/14/naomi_klein_issues_haiti_disaster_capitalism (accessed March 10, 2016).

Kruger, F., G. Bankoff, T. Cannon, B. Orlowski and L.F. Schipper. 2015. Cultures and disasters: understanding cultural framings in disaster risk reduction. New York: Routledge.

Lagos Escobar, R. 2011. Terremotos: ¿Una oportunidad para avanzar la agenda de cada Gobierno? Revista Anales Universidad de Chile 7(1): 59-75.

Letelier Troncoso, F. and P. Boyco Chioino. 2011. Talca posterremoto: una ciudad en disputa. Modelo de reconstrucción, mercado inmobiliario y ciudadanía. Santiago de Chile: Ediciones SUR.

Letelier Troncoso, F. and P. Boyco Chioino. 2013. Talca a tres años del terremoto: aprendizajes colectivos para la acción en la ciudad. Temas Sociales 70: 1-8.

Lizarralde, G., A. Valladares, A. Olivera, L. Bornstein, K. A. Gould and J.D. Barenstein. 2015. A systems approach to resilience in the built environment: the case of Cuba. Disasters 39(S1): s76-s95.

Martland S.J. 2009 Social and political fault lines: the Valparaíso earthquake of 1906. In J. Buchenao and L. L. Johnson (eds.), Aftershocks: earthquakes and popular politics in Latin America. Albuquerque: University of New Mexico Press. Pp. 70-99.

McCarthy, J., and S. Prudham. 2003. Neoliberal nature and the nature of neoliberalism. Geoforum 35(3): 275283.

McCook, S. 2002. States of nature: science, agriculture, and environment in the Spanish Caribbean, 17601940. Austin: University of Texas Press.

El Mercurio. 2010a. Catástrofe en zona centro sur de Chile February 28, C3.

El Mercurio. 2010b. La falta de instrumentos reatrasó una reacción más oportuna March 1, A13.

El Mercurio. 2010c. Los Ministros se coordinan en La Moneda, February 28, C12.

El Mercurio. 2010d. Bachelet enfrenta la peor catastrofe en decadas. February 28, A5.

El Mercurio. 2010e. Alcaldesa de Concepción critica al gobierno. March 1, C2.

El Mercurio. 2010f. Llamado desesperado a las fuerzas armadas para restaurar el orden. March 1, A5.

El Mercurio. 2011. Los drásticos cambios sufridos por la ONEMI antes de su desaparición February 27th, B15.

Mellado, C. and C. Lagos. 2014. Professional roles in news content: analyzing journalistic performance in the Chilean national press. International Journal of Communication 8: 2190-2112.

Miller, D.C. 2000. Introduction to collective behavior and collective action. Prospect Heights, Ill.: Waveland.

Mountz, A. 2012. Seeking asylum: human smuggling and bureaucracy at the border. Minneapolis: University of Minnesota Press.

Mustafa, D. 2005. The production of an urban hazardscape in Pakistan: modernity, vulnerability, and the range of choice. Annals of the Association of American Geographers 95(3): 566-586.

La Nacion. 2010. Piñera anuncia estado de catástrofe en O'Higgins March 11, http://www.lanacion.cl/pineraanuncia-estado-de-catastrofe-en-o-higgins/noticias/2010-03-11/141206.html (accessed November 22, 2013). 
New York Times. 2010. Chile says rebuilding may cost tens of billions of dollars. March 3, A8. http://www.nytimes.com/2010/03/03/world/americas/03chile.html (accessed April 15, 2012).

O'Keefe, P., K. Westgate and B. Wisner. 1976. Taking the naturalness out of natural disasters. Nature 260: 566-567.

Oliver-Smith, A. 1999. What is a disaster? Anthropological perspectives on a persistent question. In A. OliverSmith and S.M. Hoffman (eds.), The angry Earth: disasters in anthropological context. New York: Routledge. Pp. 18-34.

Oliver-Smith, A. 2002. Theorizing disasters: nature, power, and culture. In S. Hoffman and A. Oliver-Smith (eds.), Catastrophe and culture: the anthropology of disaster Oxford: School of American Research Press. Pp. 23-47.

Palacios, J. 2010. El contragolpe del empresariado a la posible alza de impuestos: proponen vender activos estatales. radio.uchile.cl, March 22. http://radio.uchile.cl/noticias/60478/

Pantti, M., K. Wahl-Jorgensen and S. Cottle. 2012. Disasters and the media. London: Peter Lang.

Pelling, M. and K. Dill. 2010. Disaster politics: tipping points for change in the adaptation of sociopolitical regimes. Progress in Human Geography 34(1): 21-37.

Pfeffer Urquiaga, E. 2002. Estados de excepción constitucional y reforma constitucional. Ius et Praxis, 8(1): 223-250.

Perry, R. and E.L. Quarantelli, E.L. (eds.). 2005. What is a disaster? New answers to old questions. Philadelphia: Xlibris Books.

Pratt, M.L. 1992. Imperial eyes: travel writing and transculturation. New York: Routledge

Presidencia [photographer]. 2010. Bachelet visita zonas afectadas y dice que aún no se conoce toda la magnitud de la tragedia. [photograph]. La Tercera, February 28, 27.

Pudim, R. [illustrator]. 2014. Illustration in Natural Hazards Observer. Natural Hazards Observer 38(3): 4.

Pulgar Pinaud, C. 2013. Chile: neoliberal and vulnerable cities. Post-disaster reconstruction and resistance. In C. Mathivet (ed.). Take back the land! The social function of land and housing, resistances and alternatives. Paris: AITEC. Pp. 32-39.

Pulgar Pinaud, C. 2014. When spatjal justice makes the neo-liberal city tremble. Social and seismic action in Chile: the aftermath of the February 27, 2010 earthquake. Justice social/Spacial Justice 6.

Radio Cooperativa. 2010. Bachelet: Esta catástrofe desnudó falencias que necesitamos corregir. March 10. http://www.cooperativa.cl/bachelet-esta-catastrofe-desnudo-falencias-que-necesitamoscorregir/prontus nots/2010-03-10/211914.html (accessed April 12, 2012)

Relea, F. 1998. La otra cara del 'jaguar' de América Latina. El País, March 23. http://elpais.com/diario/1998/03/23/internacional/890607627_850215.html (accessed April 10, 2012).

Remes, J.A.C. 2016. Disaster citizenship: survivors, solidarity, and power in the progressive era. Urbana: University of Illinois Press.

Reporters Without Borders. 2012. Press Freedom Barometer- world report: Chile. http://en.rsf.org/reportchile,171.html (accessed October 25, 2012).

Ríos Alvarez, L. 2002. Los estados de excepción constitucional en Chile. Ius et Praxis 8(1): 251-282.

Ríos Alvarez, L. 2009. Defensa judicial de los derechos humanos en los estados de excepción. Estudios Constitucionales 7(1): 277-296.

Rocheleau, D. 2008. Political ecology in the key of policy: from chains of explanation to webs of relation. Geoforum 39(2): 716-727.

Rojas, F., M. Lew and F. Naeim. 2010. An overview of building codes and standards in Chile at the time of the 27 February 2010 offshore Maule, Chile earthquake. Structural Design of Tall and Special Buildings 19(8): 853-865.

Rutland, T. 2010. The financialization of urban redevelopment. Geography Compass 4(8): 1167-1178. 
Sandoval, V. and C. Gonzalez-Muzzio. 2015. Examining 'disaster capitalism': post-disaster actions in Chile. Conference presentation. 7th i-Rec Conference 2015: Reconstruction and Recovery in Urban Contexts.

Sawislak, K. 1995. Smoldering city: Chicagoans and the Great Fire, 1871-1874. Chicago: University of Chicago Press.

Scott, J.C. 1998. Seeing like a state: how certain schemes to improve the human condition have failed. New Haven, Conn.: Yale University Press.

Smith, N. 2007. Disastrous accumulation. South Atlantic Quarterly 106(4): 769-787.

Solnit, R. 2009. A paradise built in Hell: the extraordinary communities that arise in disaster. New York: Viking.

Steinberg, T. 2006. Acts of God: the unnatural history of natural disasters in America. 2nd ed. Oxford: Oxford University Press.

Televisión Nacional de Chile. 2010. Presidente electo Piñera. Noticias Broadcast: Terremoto Chile. March 28, 18:00 hrs.

La Tercera. 2010a. Mariano Fernandez y la ayuda internacional. February 28, 27.

La Tercera. 2010b. Piñera pide decretar Estado de Catástrofe ahora mismo. February 28. http://latercera.com/contenido/674_229821_9.shtml (accessed April 10, 2012).

La Tercera. 2010c. Impacto del tsunami y saqueos agudizan magnitud de tragedia. March 1, 1.

La Tercera. 2010d. F.F.A.A. retoman control de Concepción y despliegan 11.850 efectivos tras violencia. March 1, 8.

La Tercera. 2010e. Por sicosis colectiva el comercio cierra y se produce llamado a presencia military. March 3,15

La Tercera. 2010f. Bitar: 'La idea de tener los militares en la calle no fue fácil.' March 4, 20.

La Tercera. 2010g. Privados estiman que hasta US\$ 7.000 millones podrían ser concesionados. March 23, 21.

La Tercera. 2011a. Cifras de la Catástrofe. February 27, 9.

La Tercera. 2011b. ¿Cuánto le costó el terremoto a Chile? February 20, R 24.

La Tercera. 2011c. Damnificados por el terremoto denuncian que reconstrucción de viviendas sólo llega al 10\%. December 10. http://www.latercera.com/noticia/nacional/2011/12/680-410360-9-damnificadospor-el-terremoto-denuncian-que-reconstruccion-de-viviendas-solo.shtml (accessed April 12, 2012).

Terwidt, C. 2007. The demands of the 'true' Mapuche: ethnic political mobilization in the Mapuche movement. Nationalism and Ethnic Politics 15(2): 237-257.

Tierney, K., C. Bevc and E. Kuligowski. 2006. Metaphors matter: disaster myths, media frames, and their consequences in Hurricane Katrina. The Annals of the American Academy of Political and Social Science 604(1): 57-81.

Tironi, M. 2014. Atmospheres of indagation: disasters and the politics of excessiveness. The Sociological Review 62(S1): 114-134.

Ulloa, G., and L. Cárdenas. 2010. Economistas creen que 30 mil millones para la reconstrucción es exagerado y estiman cifra menor al 50\%. Radio Bio-Bio. http://www.biobiochile.cl/2010/03/24/economistascreen-que-cifra-de-30-mil-millones-para-la-reconstruccion-es-exagerada-y-estiman-cifra-menor-al50.shtml (accessed April 15, 2012).

Vaccaro, I., O. Beltran and P.A. Paquet. 2013. Political ecology and conservation policies: some theoretical genealogies. Journal of Political Ecology 20: 255-272.

Valenzuela, C., and P. Jimeno. 2010. Gobierno buscara acelerar entrega de permisos y ampliar subsidios. La Tercera, March 11, 7.

Vásquez, C. 2010. Vecindarios de la región se arman para evitar pillaje. La Tercera, March 2, 10.

Waldman, G.M. 2012. Historical memory and present-day oblivion: the Mapuche conflict in post-dictatorial Chile. Time and Society 21(1): 55-70. 
Washington Post. 2010a. Chile reels in aftermath of quake, emergency workers provide aid. http://www.washingtonpost.com/wp-dyn/content/article/2010/02/28/AR2010022800062.html (accessed April 15, 2012).

-----. 2010b. Is Chile's new president ready to deal with an earthquake's aftereffects? Editorial. March 2. http://www.washingtonpost.com/wpdyn/content/article/2010/03/01/AR2010030102092.html?sid=ST2010030101676 (accessed April 10, 2012).

Wesselink, A. and J. Warner. 2010. Reframing floods: proposals and politics. Nature and Culture 5(1): 1-14. Williams, R. 1976. Keywords: a vocabulary of culture and society. New York: Oxford University Press.

Wisner, B. 2001. Risk and the neoliberal state: why post-Mitch lessons didn't reduce El Salvador's earthquake losses. Disasters 25: 251-268.

Wisner, B., P.M. Blaikie, T. Cannon and I. Davis. 2004. At risk: natural hazards, people's vulnerability and disasters. 2nd ed. New York: Routledge.

Whitehead, M., R. Jones and M. Jones. 2007. The nature of the state: excavating the political ecologies of the modern state. New York: Oxford University Press. 